\title{
Is Ethnic Retention a Result of Unmet Educational Aspirations? Academic Career and Ethnic Identity of Migrant Minority Youth in England, Germany, the Netherlands, and Sweden
}

\author{
Bernhard Nauck ${ }^{1}$ (D)
}

Published online: 30 June 2020

(C) The Author(s) 2020

\begin{abstract}
Data from 3 waves of the Children of Immigrants' Longitudinal Survey in 4 European countries (CILS4EU) were used to test for effects of academic trajectories on the development of ethnic retention. The large-scale comparative panel data for the transition at the end of lower secondary school provide answers to the following research questions: Is migrant youth with unmet educational aspirations especially vulnerable to ethnic retention? Is ethnic retention after failure of the academic career enhanced or buffered by societal conditions, i.e., does it vary with educational and social welfare systems? Ethnic retention was captured in 4 dimensions: social retention (ethnic friends), cultural retention (ethnic language use), religious retention (ethnic religiosity), and emotional retention (ethnic identification). Fixed-effects regressions with interaction terms tested the effects of academic track and aspirations in combination with reactive ethnicity and are tested separately for each country. As compared to Sweden, migrant minority youth in England and Germany are much more likely to develop ethnic emotions and practice a minority religion. However, in the fixed-effects analysis capturing within-individual changes, youth with increased educational aspirations but unfavorable career development did not differ substantially from the other career patterns, and if so, they showed lower levels of ethnic retention.
\end{abstract}

Keywords Ethnic identity $\cdot$ Migrant youth $\cdot$ Educational aspirations $\cdot$ Cross-national comparison

Bernhard Nauck

bernhard.nauck@soziologie.tu-chemnitz.de

1 Department of Sociology, Chemnitz University of Technology, Thueringer Weg 9,

D-09107 Chemnitz, Germany 


\section{Introduction}

Ever since the beginning of migration research and mostly driven by some skepticism toward the - at that time predominant — assimilationist perspective (Park 1950), scholars in the North American context raised the question whether migrants may react to their situation as a minority in the receiving society with increasing ethnic identification, known as reactive ethnicity. In an early version, researchers attributed reactive ethnicity to third migration generations in general (Hansen 1938), with an emphasis on rather symbolic forms of ethnicity (Gans 1979). More recently, scholars drew attention to the role of hostile interethnic relations and contextual factors such as the presence of racial discrimination for second-generation members (Portes and Zhou 1993) in accounting for the rise rather than the erosion of ethnicity, which then may become a "resilient resource" (Rumbaut 1994: 754). Within the widely discussed segmented assimilation theory (Portes and Zhou 1993; Zhou 1997), this argument developed further into a framework distinguishing three pathways of incorporation of immigrant groups: assimilation into the white middle-class mainstream, assimilation via selective acculturation and the use of ethnic resources, and downward assimilation into a socially marginalized status (Lee and Zhou 2015: 16). This resulted in the proposition that especially second- and third-generation youth on a pathway to downward assimilation were assumed to experience dissonant acculturation and to be at risk to develop reactive ethnicity (Portes and Zhou 1993: 87; Portes and Rumbaut 2001: 283; Portes et al. 2005: 1011). This proposition stands in sharp contrast to "classical, linear theory of integration into mainstream societies" (Thomson and Crul 2007: 1028), as, for example, expressed by Alba and Nee $(1997,2003)$, who assume a general decline of an ethnic distinction and cultural and social differences between ethnic groups.

In recent decades, these arguments transferred to the European context, especially with regard to second-generation migrants from North Africa and the Near East, influencing both the theoretical and public debate. On the theoretical and empirical level, strong differences between European countries with regard to the inclusion of migrant minorities resulted not only in the necessity of including the national level in the analysis of development but also in taking the diversity on various societal levels into account when explaining integration pathways (Crul and Vermeulen 2003; Thomson and Crul 2007; Crul and Schneider 2010; Crul 2016). In public debates, arguments stemming from segmented assimilation theory fueled value-laden political disputes with concerns that "home-grown extremism" was fostered among those "who are alienated or who subscribe to identities that put them at odds with "national' values" (Platt 2014: 46).

Decades ago in his analysis of ethnic identity in the USA, Richard Alba already questioned the empirical validity of ethnic revival: "Although the evidence for such a return has always been lacking, the popularity of the idea has never waned" (Alba 1990: 337). Reviews of the European context come to similar conclusions "that convincing empirical evidence of ... migrants' alleged refusal to integrate and their increasing ethnic identification and social segregation is still lacking. This is partly due to the fact that data for research on this topic are scarce and partly caused by the methodological problems of existing studies" (Diehl and Schnell 2006: 792); and, "while there have been some attempts to assess the existence of 'reactive ethnicity', there is little conclusive evidence currently in the European context" (Platt 2014: 48). 
Both assessments came to the conclusion that cross-sectional data comparing first- and second-generation migrants or cross-sectional time-series of immigrant groups are limited in their ability to provide suitable testing grounds for generational, historical, or even individual shifts in ethnic identity. "A thorough investigation of whether or not migrants in Germany are turning away from integration would require panel data" (Diehl and Schnell 2006: 787). More specifically, cross-sectional analyses are unable to test the "hypothesis that a small subgroup of migrants whose structural assimilation has failed or who have even 'assimilated downwards' might have become more homelandoriented or even more radical in their attitudes" (Diehl and Schnell 2006: 811).

The following study takes advantage of the European national variations in institutional arrangements. "Differences in educational systems (in terms of the age at which children must begin school, the number of contact hours in primary school, and the importance of early or late selection in secondary education) are a key influence" (Thomson and Crul 2007: 1032). The study analyzes large-scale panel data from England, Germany, the Netherlands, and Sweden for a very important transition in the life course of migrant minority youth, namely the end of lower secondary school. At this stage in the educational trajectory, major decisions take place which structure their educational trajectories and carry ramifications for future occupational options, income expectations, life chances, and social status. For migrant minority youth, educational transitions in the receiving society are of crucial importance, as they signal whether their aspirations with regard to structural assimilation will be met, i.e., whether they may maintain their social mobility aspirations or are vulnerable to downward mobility.

This study looks at the effects of academic trajectories on ethnic retention. It differentiates among migrant students according to their academic aspirations and their school performance with an emphasis on students with high aspirations and low performance, i.e., the downwards assimilated in the language of segmented assimilation theory. The retention of ethnic identity is conceptualized as a complex construct, including social, cultural, religious, and emotional sub-dimensions. It thus does not only comprise mental states, such as religious and emotional identification, but also the display of ethnic identity in social and cultural choices. These dimensions thus have a common theoretical background but each may potentially vary empirically in intensity. The empirical test of the downward assimilation hypothesis is adequate because (1) it is conducted with migrant minority youth of similar age cohorts from various cultural backgrounds in four European countries that differ both in educational and social welfare systems. This allows for some conclusions with regard to the impact of societal conditions on ethnic retention beyond country-specific social selectivity of migrants, such as the variation of the respective ethnic groups across countries and related attributes, such as their average educational level. And (2) the analysis uses separate fixed-effects models for each country to observe if changes in school tracks and educational aspirations impact ethnic retention. As this analysis controls for unobserved heterogeneity in the population, it is most appropriate for analyzing the effects on ethnic retention in the heterogeneous population of migrant minority youth. This especially high heterogeneity is, among others, a result of differences in the respective family culture and has been described in various studies about styles of parenting practices, intergenerational transmission of values, and investments into the social placement of the offspring. Unlike classical regression approaches, these antecedents 
must not be explicitly controlled for in fixed-effects models (unless there are theoretical reasons to assume that they change systematically during the observation period).

This research design is particularly suited to answer research questions related to the downward assimilation hypothesis: Is migrant minority youth with unmet educational aspirations especially vulnerable to ethnic retention? Do they show anything like reactive ethnicity, i.e., an increase of their ethnic identification when the academic career fails? After failure of the academic career, is reactive ethnicity enhanced or buffered by societal conditions, i.e., does ethnic retention vary with cultural difference in interethnic relations, or by the educational and social welfare systems? And specifically, does late tracking make an academic career look more flexible and less fateful and thus give less occasion for ethnic retention? Do welfare state provisions enhance or buffer the subjective consequences of unmet educational aspirations?

\section{Educational Career and Ethnic Identity}

Mainstream research on the relationship between ethnic identity and the course of educational careers tries to explain why students of different ethnic identities vary in educational aspirations, efforts, and investments in educational careers and academic achievements and successes. In most cases, such studies relied on the well-established status attainment model, linking the social status and resources of parents to the academic achievements and later social statuses of their offspring. To explain variations in educational investment strategies, scholars used this model to account for ethnic differences as composition effects from parental resources or as interaction effects between resources and cultural features of respective ethnic groups (Lee and Zhou 2015; Liu and Xie 2016; Nauck 2019). Moreover, this model was used to analyze the effects of assimilation to and identification with the respective receiving society on educational and occupational outcomes (see, e.g., for the case of ethnic religiosity: Connor and Koenig 2013; Cheung 2014; Koenig et al. 2016; Ohlendorf et al. 2017). The following analysis shifts the focus to how educational trajectories may or may not lead to changes in ethnic identity. Thus, rather than ethnic identity as an antecedent, it looks at it as an outcome of the course of educational careers and, more specifically, whether downward mobility in the educational system enforces ethnic retention or even induces reactive ethnicity.

When studying ethnic retention at the individual level empirically, ethnic identity is treated as a multidimensional concept covering several aspects of social behavior (Heath et al. 2018). It includes social retention as the extent adolescents have friends of the same ethnic origin; cultural retention as the amount adolescents use an ethnic language from their country of origin, when speaking, reading, and writing or when consuming mass media; religious retention as the degree of religiosity adolescents express in a minority religion, i.e., in a religion not common in the majority population; emotional retention as the strength of identification by adolescents with their minority group. Generally, these aspects of ethnic retention are positively related to each other (Berry et al. 2006; Leszczensky 2018), but the intensity may vary considerably and the mechanisms that influence retention may differ (Jacob and Kalter 2013). For example, the extent of religious and emotional retention is unconditional, as they do not depend on opportunity structures, whereas social and cultural retention are conditional, as they 
are based on opportunities such as the availability of same-ethnicity-peers or of ethnic mass media.

This conceptualization does not imply that ethnic retention and incorporation into the receiving society are mutually exclusive. For example, migrant minority adolescents with many friends from within their ethnic group may also have many friends from the majority (or none or few from both groups), and those who frequently consume ethnic mass media may also be those with the highest usage of majority mass media. Thus, this conceptual approach of ethnic retention does not distinguish between discrete acculturation strategies (Berry 1997), as it does not consider the level of adoption of the culture of the majority population (see, e.g., Diehl et al. 2016 for a complementary perspective).

The relationship between ethnic retention of migrant minority youth and their educational aspirations is of major importance due to two empirical preconditions. On the one hand, they maintain remarkably high educational aspirations, even higher than the aspirations of native youth on average. This phenomenon was coined early on as "immigrant optimism" in the American context (Kao and Tienda 1995, 1998; Glick and White 2004) and resulted in a series of empirical investigations which consistently replicated the finding for immigrant youth in Germany (Becker and Gresch 2016; Dollmann 2010; Kristen and Dollmann 2010; Relikowski 2012; Relikowski et al. 2012; Salikutluk 2016). Additionally, a comparative analysis based on the CILS4EU data revealed that immigrant youth in England, Germany, the Netherlands, and Sweden showed consistently higher educational aspirations than their native counterparts (Nauck and Genoni 2019). On the other hand, migrant minority youth show low levels of educational attainment relative to native youth on average. Based on the status attainment model, empirical studies revealed that children from migrant families from most countries of origin were disadvantaged in their school performance because of lower economic, cultural, and social capital among their parents (van de Werfhorst and Tubergen 2007; Relikowski et al. 2010; Dollmann 2010; Becker and Beck 2012; Relikowski 2012), with the exception of families from East Asia (Lee and Zhou 2015; Nauck and Schnoor 2015). Moreover, when differentiating between primary and secondary effects of social origin, analyses based on the status attainment model demonstrated a significant positive effect of educational aspirations on educational success. However, the status attainment model does not make predictions about the consequences for migrant minority youth with high aspirations that are not met by a successful academic career. Instead, this pathway, as identified in the upper-right-hand cell of Table 1, is specifically the focus of the downward assimilation hypothesis, whereas the educational attainment model focuses on those in the lower-right-hand cell.

One rigorous test of the downward assimilation hypothesis was whether ethnic retention resulting from low educational aspirations was moderated by the societal conditions in a respective country, i.e., was ethnic retention enhanced or buffered by the educational or social welfare systems. The included countries of England, Germany, the Netherlands, and Sweden vary in this regard (Jonsson 2018; Nauck and Genoni 2019), but also on other dimensions, such as the general and subsystem-specific integration policies: On the MIPEX index (CIDOB and MPG 2015), Sweden shows the highest value (with a score of 80 in 2014), while Germany (63), the Netherlands (61), and the UK (56) reveal policies being less favorable for immigrant integration (Hadjar and Scharf 2019: 716). 
Table 1 Receiving countries in comparison

\begin{tabular}{|c|c|c|c|c|}
\hline & England & Germany & The Netherlands & Sweden \\
\hline Welfare regime & Liberal & Conservative & Conservative & Social democratic \\
\hline $\begin{array}{l}\text { Connection of educational } \\
\text { success and social security }\end{array}$ & Strong & Medium & Medium & Weak \\
\hline First tracking & At age 16 & At age 10 & At age 12 & At age 16 \\
\hline Selection mechanism & Choice driven & Selection driven & Selection driven & Choice driven \\
\hline
\end{tabular}

Following the typology of welfare regimes developed by Esping-Andersen (1990), the four countries are classified as follows: In Europe, England is the prototype of a liberal welfare state, based on principles of market individualism and competition. Welfare state provisions are minimal, leading to high levels of social inequality based on individual resources and meritocracy rewarding skills and related certificates. Germany and the Netherlands constitute a conservative welfare state type, based on communitarian values, which implies that state interventions are stronger, but subsidiary to the role of primary groups in determining the social status and placement of their members. Sweden remains the prototype of a social democratic welfare state favoring extensive state interventions targeted at decreasing social inequality through income redistribution measures and providing equal opportunities to citizens via an extensive state-run infrastructure (Kaufmann 2013).

The overarching social welfare system of a country overlaps with the educational system as their institutions stem from similar foundations and principles (Allmendinger and Leibfried 2003; Allmendinger and Nikolai 2010; West and Nikolai 2013). Across the four countries, England stands out with low state expenditures for education, partially offset by high private expenditures, including those for mostly unsubsidized private schools. In contrast, Sweden has a universal public education system involving high state expenditures with low additional costs for parents, and full inclusivity across the educational career of students. The Netherlands and Germany are in between, with the Netherlands being closer to Sweden, whereas the educational system of Germany traditionally institutionalizes parental involvement with its part-time schooling, thus contributing to social inequality in educational achievement. Both countries have early tracking in common, but differ with regard to parental influence on track placements of students. In the Netherlands, placement is decided by school principals based on final exams and teacher's recommendations only (Dronkers and Korthals 2017: 150). In Germany, there are more opportunities for parental choices and interventions, with some variation among states due to its federal constitution (Van de Werfhorst and Mijs 2010). Interestingly, ability tracking is institutionalized in England as late as in Sweden, but is counterbalanced by vertical differentiation between private and public schools, and, more importantly, by various forms of school-internal differentiation practices in both countries (Rudolphi and Erikson 2017; McMullin and Kulic 2017).

The four countries also differ with regard to the transition from education to occupation. Corresponding with liberal welfare state and education principles, institutionalization of this transition is low in England, resulting in a competitive and insecure situation with a high proportion of adolescents unable to access vocational training or 
employment. Both the social democratic and conservative systems provide institutionalized transitions from school-to-work, either with vocational training fully included in public schooling in Sweden or with the dual system of vocational educational and training (VET) in Germany and its institutionalized cooperation between private firms and public schools (Hensen-Reifgens and Hippach-Schneider 2014). For the Netherlands, Crul (2018) demonstrates that the complicated institutional structure of the educational system requires many choices in the academic trajectory, disadvantaging parents and students with less knowledge about the consequences of the various pathways and resulting in structural inequalities in the transition from the educational to the occupational system.

Two possible mechanisms may link societal conditions to educational deprivation at the individual level: (1) The strong connection between educational attainment and individual welfare in liberal welfare regimes increases adverse consequences of low levels of educational attainment, whereas the extended re-distributive provisions in social-democratic welfare regimes buffer these consequences through a decoupling of individual welfare from educational attainment to some extent, i.e., decommodification of educational achievement. Accordingly, this suggests that among these four countries, migrant minority youth in England are the most likely to develop ethnic retention due to low educational expectations, whereas migrant minority youth in Sweden are least likely to develop ethnic retention (H1). (2) The timing of tracking in the educational trajectory and whether the tracking-decision takes place more or less in the educational system or in the migrant family may also impact the perceived consequences of educational attainment. The earlier the tracking and the more the decision is allocated to the educational system and not to the parents and students, the less perceptible self-efficacy and situational control leading to a higher likelihood of the migrant minority youth developing reactive ethnicity. Accordingly, this suggests that migrant minority youth in Germany and the Netherlands, where early tracking can be "imposed" by the educational system, are alternatively more likely to develop ethnic retention than migrant minority youth in England and Sweden, where tracking is more choice driven and takes place later in the educational trajectory (H2). These mechanisms may act as countervailing forces to some extent in England and Sweden with somewhat antithetical social welfare regimes, but similar tracking systems. Moreover, only a very indirect empirical test of such macro-micro-hypotheses is possible and relies on rather strong theoretical presumptions. Because of the hyper-complex characteristics of the respective societies and the few cases, it is impossible to isolate the effects of single mechanisms (Kittel 2006). Instead, the hyper-complexity is used to increase the variability on the contextual level to make the empirical test on the individual level more rigorous.

\section{Data, Variables, and Analytic Strategy}

The empirical analyses are based on the first 3 waves of the Children of Immigrants Longitudinal Survey in Four European Countries (CILS4EU). The 1st wave was collected in 2010-2011 from the student populations in England, Germany, the Netherlands, and Sweden (Kalter et al. 2016, 2019). For the initial wave, a two-step cluster design was used: Schools were selected, and those with a high proportion of 
migrant minority youth were over-sampled, then within each school, two randomly drawn classes were sampled. Students at 14-15 years of age in 952 classes in 480 schools filled out questionnaires and took tests during two school hours. The school participation rate ranged between 66 (England) and 99\% (Germany), and the student participation rate between 81 (England) and 92\% (the Netherlands). The national data sets are representative for the native and migrant student population of this age (final $n=18,716$ ). Students with a migration background are heterogeneous with regard to their country of origin and migrant generation. $21.9 \%$ belonged to the 1 st generation, the majority $(56.9 \%)$ to the 2 nd, and $21.2 \%$ to the 3 rd generation. The 2 nd wave retained 15,790 participants 1 year later and the $3 \mathrm{rd}$ wave another year later included 10,603 participants from the 1st wave. In England and Sweden, the students were asked via postal/electronic mail to fill out an online questionnaire. In Germany, data collection took place via telephone (and web in a follow-up attempt). Another school survey was conducted in the Netherlands, which was complemented by a web survey for adolescents who already left school. The following analyses use data from migrant minority youth only.

Four dimensions of ethnic retention were captured using composite measures. Social retention consists of information about the minority membership of one's friends in general and the 5 best friends in particular. Cultural retention is a composite of selfrated proficiency in the respondent's ethnic language and its usage in several situations, such as communication with family members and friends and mass media usage ( 8 items). Religious retention is a composite measure of the degree of religiosity in a nonChristian minority religion (4 items). Emotional retention is a composite measure of identification with the respondent's ethnic minority ( 3 items). All four measures were standardized by z-transformations across all panel waves and countries.

The central predictor of ethnic retention is the relation and the development over time between educational aspirations and attainment (Table 2). Educational aspiration is a composite measure of idealistic and realistic aspirations regarding the final educational grade ( 2 items). Idealistic and realistic aspirations were strongly correlated $(r=.73, p<.001)$. The measure was dichotomized at the median. Educational attainment is a dichotomous variable. Students were differentiated based on placement in an academic school track or not. In cases where school tracks were not institutionalized, placement within the school that would lead predominantly to higher education was considered an "academic track".

For analytical and comprehension purposes, the four categories in the model are labeled according to educational achievements in relation to students' own aspirations as "low"-, "high"-, "under"-, and "over"-achievers. Of special interest in this analysis are the under-achievers.

Table 2 Analytical model (cell percentages, 22,776 observations)

\begin{tabular}{llll}
\hline & & \multicolumn{2}{l}{ Educational aspirations } \\
\cline { 3 - 4 } & & Low & High \\
\hline Educational attainment & Non-academic track & $38.5 \%$ "low-achievers" & $21.6 \%$ "under-achievers" \\
& Academic track & $11.4 \%$ "over-achievers" & $28.4 \%$ "high-achievers" \\
\hline
\end{tabular}


The empirical analysis includes three consecutive steps. At first, the development of ethnic retention across the three waves for each country is presented as marginal mean values, adjusted for the time-invariant variables. In a second step, data of all three waves were pooled and analyzed for cross-sectional associations of predictors and moderators on ethnic retention. Finally, fixed-effects models tested the effects of educational aspirations and attainment on ethnic retention within-individuals over time, with a special emphasis on migrant minority youth with high aspirations and low attainment.

Whereas the fixed-effects models include only the time-varying covariates of educational aspirations, academic track, and their interactions, the cross-sectional models also include time-invariant controls for sex, age of the respondent, and migrant status (having migrated her/himself or not). Parents' level of education is coded into the six-category version of CASMIN (Müller and Shavit 1998); first from the selfreport of parents, or, second, from the report of the student. In case information for both parents is available, the average is taken. In order to establish a comprehensive concept of cultural difference, the analysis follows the well-established approach of Hofstede (2001); Hofstede et al. 2010). From various sources, Hofstede has collected individuallevel values and attitudes, aggregated and factor-analyzed them on the national level, providing relevant dimensions for the description of national cultures within a global context. Using the aggregate indicators, cultural difference is measured by the sum of absolute differences between the scores on the six Hofstede-dimensions "power distance," "uncertainty avoidance," "individualism," "masculinity," "long term orientation," and "indulgence" between the receiving society and the respective society of origin of the migrant family (Nauck and Genoni 2019). Unfortunately, the CILS4EUdataset does not contain additional time-varying variables, which may be influential for the development of ethnic retention. For example, one may assume that parental interventions, such as stricter control and supervision in case of academic failure may accelerate ethnic retention, or that an increased empathic parenting style may buffer the relationship between academic career and ethnic retention.

Table 7 in the Appendix displays all included model-variables in the cross-sectional and panel analyses. It demonstrates strong differences between the migrant adolescents in the four countries. England had the highest share of adolescents, who migrated themselves. Their parents were comparably well-educated and they had the highest share of students in the academic track, but also with the highest likelihood of downward track mobility. Whereas their religious retention was the highest, they had at the same time the lowest level of cultural retention, which might be caused by the fact that many migrants tem from former British colonies, where the English language was common. The German migrant minority youth showed on average the lowest cultural difference to the majority population. Their parents' educational level was the lowest among all four receiving countries, as was their share on the academic track. Their educational aspirations were much lower, whereas the social and emotional retention was higher than that of the migrant adolescents in the other countries. The adolescents in the Netherlands had the smallest share of 1st generation migrants, showed the lowest level of social retention, and comparably low rates of track mobility. The migrant adolescents in Sweden belonged to ethnic groups with the highest cultural difference and came from families with the highest educational level. They showed the highest upward track mobility and combined high levels of cultural retention with low 
levels of religious and emotional retention. In terms of segmented assimilation theory, one may conclude that the profile of the Swedish migrant adolescents fits the type of selective acculturation using ethnic resources that those from the Netherlands and England correspond to some extent to the assimilation into the middle-class mainstream, whereas the German migrant adolescents seem to have several characteristics of downward assimilation.

\section{Results}

Table 3 displays the means of the four ethnic retention variables across the three waves, adjusted for sex, migrant status, cultural difference between the country of origin of the migrant minority youths and their receiving society, and their parents' education level. The adjustment thus controls for the most relevant composition effects between countries, as these countries attracted very different ethnic groups (Jonsson 2018; Kalter and Heath 2018): Whereas the three most frequent countries of origin in England were (in this order) Pakistan, Jamaica, and India, these migrant adolescents in Germany were from Turkey, Russia, and Poland; in the Netherlands from Turkey, Morocco, and Suriname; and in Sweden from Iraq, Finland, and Turkey.

Table 3 Changes in ethnic retention between waves 1-3 (adjusted means, standard errors in brackets)

\begin{tabular}{|c|c|c|c|}
\hline Country & W1 (2010-11) & W2 (2011-12) & W3 (2012-13) \\
\hline \multicolumn{4}{|c|}{ Social Retention } \\
\hline England & $.005(.020)$ & $.168(.023)$ & $.043(.028)$ \\
\hline Germany & $.183(.018)$ & $.255(.020)$ & $.115(.022)$ \\
\hline Netherlands & $-.118(.022)$ & $-.208(.026)$ & $-.493(.032)$ \\
\hline Sweden & $-.192(.018)$ & $-.052(.020)$ & $-.064(.025)$ \\
\hline \multicolumn{4}{|c|}{ Cultural Retention } \\
\hline England & $-.200(.020)$ & $-.550(.023)$ & $-.517(.027)$ \\
\hline Germany & $.350(.017)$ & $-.010(.020)$ & $-.121(.021)$ \\
\hline Netherlands & $.150(.021)$ & $.014(.025)$ & $-.193(.031)$ \\
\hline Sweden & $.357(.018)$ & $.040(.020)$ & $-.016(.024)$ \\
\hline \multicolumn{4}{|c|}{ Religious Retention } \\
\hline England & $.108(.019)$ & $.224(.023)$ & $.432(.027)$ \\
\hline Germany & $.146(.017)$ & $.168(.019)$ & $.115(.021)$ \\
\hline Netherlands & $.060(.021)$ & $.038(.025)$ & $-.141(.031)$ \\
\hline Sweden & $-.383(.017)$ & $-.287(.020)$ & $-.314(.024)$ \\
\hline \multicolumn{4}{|c|}{ Emotional Retention } \\
\hline England & $.146(.020)$ & $.205(.023)$ & $.161(.027)$ \\
\hline Germany & $.247(.018)$ & $.233(.020)$ & $.117(.022)$ \\
\hline Netherlands & $.056(.022)$ & $.001(.026)$ & $-.068(.031)$ \\
\hline Sweden & $-.370(.018)$ & $-.343(.020)$ & $-.383(.025)$ \\
\hline
\end{tabular}

Means adjusted for sex, migrant status, cultural distance, and parents' education 
The main result of the adjusted means is that ethnic orientations generally decreased or remained stable within the observed age range in all four countries: The use of an ethnic language and the consumption of mass communication in that language decreased as did the choice of friends from a minority background. Emotional retention remained stable across waves. Minority religiosity demonstrates mixed trajectories: Whereas it slightly decreased across the survey waves in Germany and the Netherlands, a small increase was observed for Sweden, and an exceptionally strong increase for England. However, this exception does not allow for the conclusion of a reactive ethnicity among migrant minority youth, as the general trend points either at stability or heterogeneous directions depending on context, i.e., no general trend.

From an acculturation perspective, Table 3 displays another important finding: In all four societies and for all four ethnic retention indicators, the standard errors increased systematically with the age of the respondents. Thus, educational trajectories and exposure to the receiving society and its educational system did not lead to an acculturative homogenization of the migrant minority youth, but to an increasing diversification in their ethnic orientations.

Pooled information from all three waves are used for an OLS-regression of ethnic retention on both time-constant variables and the important academic and aspirational factors; results are displayed in Table 4.

Among the four dimensions of ethnic retention, religious retention varied most with the included predictors, followed by emotional and cultural retention, whereas social retention showed only minor differences between countries and conditions. Among the predictors, cultural difference between the country of origin and the receiving country had the strongest impact on ethnic retention with a significantly different from zero positive coefficient in all cases. Thus, the greater the cultural difference, the higher the likelihood of ethnic retention. This is strong with regard to social and emotional retention and especially strong for religious retention.

The respective receiving country had a strong impact on ethnic retention. Each respective receiving country showed variation in ethnic retention after accounting for

Table 4 Ethnic retention of migrant youth (OLS-regression of pooled data from 3 waves)

\begin{tabular}{|c|c|c|c|c|}
\hline & Social R. & Cultural R. & Religious R. & Emotional R. \\
\hline England ${ }^{\mathrm{a}}$ & $.082 * * *$ & $-.213 * * *$ & $.237 * * *$ & $.228 * * *$ \\
\hline Germany $^{\mathrm{a}}$ & $.158 * * *$ & $-.020 *$ & $.250 * * *$ & $.277 * * *$ \\
\hline Netherlands ${ }^{\mathrm{a}}$ & $-.041 * * *$ & $-.039 * * *$ & $.133 * * *$ & $.145^{* * * *}$ \\
\hline Male & -.006 & $-.036^{* * *}$ & $.027 * * *$ & $.018 * *$ \\
\hline Age & $.017 * * *$ & $.004 *$ & $.016^{* * *}$ & .000 \\
\hline Parents' education & $-.089 * * *$ & .011 & $-.150 * * *$ & $-.104 * * *$ \\
\hline Cultural distance & $.281 * * *$ & $.085^{* * *}$ & $.368^{* * *}$ & $.284 * * *$ \\
\hline Migrant status & -.010 & $.215^{* * *}$ & $-.045 * * *$ & $.083 * * *$ \\
\hline Academic track & $-.045^{* * *}$ & $-.052 * * *$ & $-.046^{* * *}$ & $-.052 * * *$ \\
\hline Educational aspirations & $.046^{* * *}$ & $-.035 * * *$ & $.080 * * *$ & $.032 * * *$ \\
\hline$R^{2}$ & .093 & .111 & .165 & .138 \\
\hline
\end{tabular}

a Reference: Sweden; * $p<.05 ; * * p<.01 ; * * * p<.001$ 
the impact of covariates: As compared to Sweden, immigrant youth in England, Germany, and the Netherlands showed much higher levels of emotional and religious retention, and in England and Germany they showed slightly higher levels of social retention all else equal. Alternatively, immigrant youth in Sweden showed the highest level of cultural retention, i.e., maintenance of their ethnic language usage. As the analysis controlled for cultural difference and key socio-economic covariates, this suggests that this finding is not the result of composition effects of the migrant population, but is related to differences between the educational and/or social welfare regimes.

Higher education of parents and academic tracks for their children were negatively associated with ethnic retention with 7 out of 8 significant regression coefficients. This result is consistent with theories of religious and emotional retention because higher education is usually associated with lower levels of religiosity and national or ethnic identification in favor of a more cosmopolitan orientation. However, the result was somewhat unexpected with regard to social and cultural retention, as higher education is generally associated with double-integration in both the minority and majority contexts. Although the maintenance of the minority language and culture should be available to these migrants with more resources and learning, they do not show retention to the same degree as those without these resources.

Finally, there is a notable moderate positive association of high educational aspirations with religious, emotional, and social retention. Whereas this finding is hardly compatible with the downward assimilation hypothesis, it may be an indication of the supportive role of social integration of migrant minority youth in ethno-religious communities (Bankston III and Zhou 1995).

Based on the pooled data for all three waves in a cross-sectional analysis, Table 5 displays the means and standard deviations of ethnic retention according to whether or not their educational career has met their aspirations. Again, results are adjusted to control for composition differences in the migrant population between countries. According to the downward assimilation hypothesis, migrant minority youth with high educational aspirations in a non-academic track (the under-achievers) should be most likely to maintain high levels of ethnic retention.

In fact, the analysis revealed that the under-achievers had the highest likelihood for cultural retention in Germany, for emotional retention in Germany and the Netherlands, and for social and religious retention in England, Germany, and the Netherlands. This may be seen as some empirical support for an association between ethnic retention and the academic career, at least in three out of the four countries. Notably, the underachieving migrant minority youth in Germany showed the highest level of ethnic retention in all four dimensions, whereas in Sweden they showed this pattern in none of the four dimensions. This may again be taken as an indication that the social democratic educational system and welfare regime have some buffering effects on the individual consequences of academic careers.

Whereas the analysis in Table 5 is adequate for identifying time-constant influences on ethnic retention, such as level differences between countries, it is not ideally suited for handling time-varying factors such as the effects of the development of educational careers on ethnic retention; or, any effects of the time-varying variables such as educational track and aspiration are likely due to between-individual rather than within-individual differences. 
Table 5 School performance and ethnic retention (adjusted means, standard errors in brackets)

\begin{tabular}{lcccc}
\hline Country & low-achievers & over-achievers & under-achievers & high-achievers \\
\hline Social Retention & & & & \\
EN & $-.056(.027)$ & $.073(.036)$ & $.135(.026)$ & $.098(.023)$ \\
GE & $.235(.015)$ & $.151(.027)$ & $.277(.050)$ & $.012(.029)$ \\
NL & $-.154(.024)$ & $-.496(.058)$ & $.008(.031)$ & $-.437(.027)$ \\
SW & $-.206(.025)$ & $-.138(.048)$ & $-.129(.020)$ & $-.040(.020)$ \\
Cultural Retention & & & & \\
EN & $-.217(.027)$ & $-.368(.035)$ & $-.407(.026)$ & $-.494(.022)$ \\
GE & $.155(.015)$ & $.000(.027)$ & $.217(.049)$ & $.039(.029)$ \\
NL & $.154(.024)$ & $-.107(.057)$ & $.099(.031)$ & $-.144(.026)$ \\
SW & $.156(.024)$ & $.258(.048)$ & $.186(.020)$ & $.117(.020)$ \\
Religious Retention & & & \\
EN & $.061(.026)$ & $.154(.034)$ & $.318(.025)$ & $.289(.022)$ \\
GE & $.157(.014)$ & $.121(.026)$ & $.342(.048)$ & $.046(.028)$ \\
NL & $.033(.023)$ & $-.146(.056)$ & $.247(.030)$ & $-.160(.026)$ \\
SW & $-.372(.024)$ & $-.322(.047)$ & $-.343(.020)$ & $-.301(.020)$ \\
Emotional Retention & & & & \\
EN & $.174(.026)$ & $.186(.035)$ & $.168(.026)$ & $.153(.022)$ \\
GE & $.250(.015)$ & $.095(.027)$ & $.321(.049)$ & $.133(.029)$ \\
NL & $.101(.023)$ & $-.221(.056)$ & $.218(.031)$ & $-.199(.026)$ \\
SW & $-.520(.024)$ & $-.338(.047)$ & $-.308(.020)$ & $-.324(.020)$ \\
\hline
\end{tabular}

Means adjusted for sex, migrant status, cultural distance, and parent's education

One major problem in this regard is the possibility of reverse causality. For example, it might well be that educational aspirations and investments into an academic career of migrant parents and youth may vary with their levels of ethnic retention. Therefore, the analysis in Table 6 makes full use of the panel structure of the data and applies fixed-effects models to test the effects of educational aspirations and placement in the tracking system on changes in ethnic retention within individual migrant students over time. Moreover, to explicitly test the downward assimilation hypothesis, an interaction effect of being in a nonacademic track with high educational aspirations is included in the models. This fixedeffects approach also controls unobserved heterogeneity by modeling respondent-specific intercepts. This is of special importance for the case of cross-national comparisons with varying compositions of ethnic backgrounds among migrant minority youth.

The fixed-effects models revealed that changing into an academic track had little association with ethnic retention. Although 3 out of 4 coefficients were negative suggesting that it diminished, the only one that was significant was for the Netherlands, where the preference for friends from the ethnic minority decreased substantially. Increasing educational aspirations within the observed period had diverging effects on the four dimensions of ethnic retention. On the one hand, it resulted in decreased cultural retention, with a significant loss of ethnic language use in England and Sweden. On the other hand, it coincided with an increased social retention in the Netherlands and Sweden, an increased 
Table 6 Effects of the academic career on ethnic retention (fixed-effects coefficients, standard errors in brackets)

\begin{tabular}{lllll}
\hline Country & England & Germany & Netherlands & Sweden \\
\hline Social retention & & & & \\
Educational aspirations & $-.054(.052)$ & $-.025(.047)$ & $.134 *(.058)$ & $.137 *(.068)$ \\
Academic Track & $.026(.057)$ & $-.054(.044)$ & $-.192^{*}(.092)$ & $-.113(.072)$ \\
Educational aspirations * Low track & $.089(.066)$ & $.096(.070)$ & $-.184 * *(.069)$ & $-.163 *(.077)$ \\
Constant & $-.009(.036)$ & $.147 * * *(.017)$ & $-.144 * * *(.036)$ & $-.013(.035)$ \\
Cultural retention & & & & \\
Educational aspirations & $-.203 * * *(.043)$ & $-.064(.042)$ & $-.107(.064)$ & $-.128^{*}(.055)$ \\
Academic Track & $.052(.047)$ & $-.170^{* * *(.040)}$ & $-.082(.102)$ & $-.041(.057)$ \\
Educational aspirations * Low Track & $.045(.055)$ & $.022(.063)$ & $.045(.076)$ & $.074(.061)$ \\
Constant & $-.291 * * *(.030)$ & $.147 * * *(.015)$ & $.096 *(.040)$ & $.279 * * *(.028)$ \\
Religious retention & & & & \\
Educational aspirations & $.190 * * *(.039)$ & $.046(.026)$ & $.030(.041)$ & $.102 * *(.034)$ \\
Academic Track & $-.070(.043)$ & $.009(.024)$ & $-.064(.065)$ & $-.031(.036)$ \\
Educational aspirations * Low Track & $-.021(.050)$ & $-.025(.039$ & $.001(.048)$ & $-.059(.039)$ \\
Constant & $.042(.027)$ & $.066 * *(.009)$ & $.078 * *(.026)$ & $-.257 * * *(.018)$ \\
Emotional retention & & & & \\
Educational aspirations & $-.073(.030)$ & $.025(.045)$ & $.033(.065)$ & $.117 *(.063)$ \\
Academic Track & $.030(.055)$ & $-.079(.043)$ & $-.106(.104)$ & $.046(.066)$ \\
Educational aspirations * Low Track & $-.011(.064)$ & $-.091(.068)$ & $-.026(.078)$ & $.015(.070)$ \\
Constant & $.139 * * *(.034)$ & $.173 * * *(.016)$ & $.072(.040)$ & $-.377 * * *(.032)$ \\
\hline & & & &
\end{tabular}

$* p<.05 ; * * p<.01 ; * * * p<.001$

religious retention in England and Sweden, and an increased emotional retention in Sweden. Thus, in general, the psychological dynamics of individual aspirations and ethnic retention behavior are more important than the objective or perceived consequences of educational mobility in the respective tracking system.

Of crucial importance for the test of the downward assimilation hypothesis are the results for the interaction effect between placement in the non-academic track and high educational aspirations. The overall picture here was that deprived educational aspirations generally decreased ethnic retention. The only exceptions were observed for England, where an (insignificant) increase of cultural and social retention took place. The only two significant interaction effects were negative: In the Netherlands and in Sweden, deprived educational aspirations resulted in a decrease of social retention, i.e., in a loss of ethnic friends.

\section{Discussion}

Ongoing discussions about reactive ethnicity of migrant minority youth were recently fueled by the widely debated segmented assimilation theory positing that migrant minority youth on a pathway to downward assimilation are especially likely to retain or even reinforce ethnic identity. The presented analysis contributes 
to this discussion with a longitudinal test of reactive ethnicity at a significant stage in the life-course of migrants. This study observed migrant minority youth at the transition from lower secondary school when they either enter into vocational training or unskilled labor (non-academic track) or remain in school and are on a path directly toward higher education (academic track). It compared the development of ethnic retention for migrant minority youth categorized by low or high academic aspirations and academic versus non-academic tracking.

This helped identify those under-achievers whose high academic aspirations were not met due to a non-academic school career and thus were on a downward assimilation trajectory. As opposed to low-achievers (low aspirations on the nonacademic track), high-achievers (high aspirations on the academic track) and overachievers (low aspirations on the academic track), this is the group that helps empirically adjudicate between the predictions of downward assimilation and reactive ethnicity. The test was conducted with panel data from the four countries England, Germany, the Netherlands, and Sweden and comprised 3 waves over an observation period of 2 years. This allowed not only answering the leading research question, whether downward assimilation results in an increased likelihood of ethnic retention or even reactive ethnicity, but also to answer the additional research question, whether ethnic retention is moderated by the societal conditions of the respective receiving country.

As for the first research question, the empirical results were that migrant minority youth did not show general trends of reactive ethnicity, as social, cultural, and emotional retention decreased or remained stable within the observed period in all four countries. A notable exception, however, was the marked increase of religiosity among the migrant minority youth in England, which should be of special interest for future research (Table 3).

A pooled cross-sectional comparison of the under-achievers with the other three types revealed that they showed the highest likelihood of ethnic retention in ten of the possible 16 cases (of four types of retention in four countries). This crosssectional finding from Table 4 could be taken as some support for the downward assimilation hypothesis. It might also be the case that impressions from similar findings in previous research, focusing on such exceptional cases, contributed to the longstanding prominence of this hypothesis. However, these findings are only general mean differences across migrants. A robust test of the hypothesis requires changes within individual migrants in ethnic retention that coincide with changes in the school career, as provided in Table 6. Here, results revealed that changing tracks had mostly no effects on ethnic retention. In only rare cases were small, generally diminishing effects on ethnic retention observed. Crucial for the test of the downward mobility hypothesis was the interaction effect of track mobility and aspirations. The results clearly revealed effects opposing the hypothesis, because most coefficients were negative and many not significantly different from zero, whereas the downward mobility thesis predicts positive and significant effects. Thus, the answer to the first research question is that the empirical results do not provide any support for the assumption that downward assimilation results in an increased likelihood of ethnic retention in the context of the countries under study, but they provide some tentative support for the opposite to the hypothesis at least 
in terms of a general negative coefficient direction, two of which were significant for the case of social retention.

As for the second research question, the empirical results showed marked differences in ethnic retention levels of migrant minority youth in England, Germany, the Netherlands, and Sweden, even though composition effects of the migrant population in the respective countries were controlled for (Table 4). Among these countries, migrant minority youth from England and Germany showed the highest level of emotional and religious retention. Sweden stood out with a consistently high level of cultural retention among all four types of school performance, i.e., ethnic language usage, whereas social, religious, and emotional retention was consistently well below average (Table 5). The high level of cultural retention may be related to the Swedish policy of encouraging language maintenance and teaching the languages of origin at school (Salö et al. 2018), whereas the low levels on the other retention-dimensions may be related to the fact that in "policies of integration ... Sweden is constantly ranked first, independent of which index we rely on" (Jonsson 2018: 54). Contrary to the effects of school transitions on well-being of migrant minority youth in these countries (Nauck and Genoni 2019), ethnic retention seemed to be less related to the educational system. At least early or late tracking, which divides Germany and the Netherlands from England and Sweden, did not associate with systematic variations of ethnic retention between countries. The exception is the combination of early tracking with a conservative education and welfare regime in Germany that seemed to increase the likelihood of ethnic retention. However, these conclusions rely heavily on the initial assumption that the predominant link between macro-societal conditions and ethnic retention is constituted by the respective connections of educational success with social security and with the educational tracking system (Table 1).

Beyond its contribution to these two specific research questions, the analysis also resulted in some findings which are of relevance for the understanding of immigrant incorporation processes in general. Levels of education, both of migrant minority youth and their parents, were systematically associated with ethnic retention, as the coefficients were almost always negative when other factors were controlled. This result is partly unexpected from an acculturation strategies perspective (Berry 1980, 1997; Nauck 2008), within which education is considered to be a major precondition of double integration in both the minority and majority society and culture. Instead, the results suggest that education amplifies a substitution effect favoring assimilation instead of dual-integration as the dominant pathway among the better educated, resourceful migrant minority youth. This somewhat unexpected empirical finding was complemented by results from Table 3, showing increasing variance with age for all four indicators of ethnic retention in all four countries. Although exposure to the receiving societies and their educational system associates with less ethnic retention on average, it did not result in increased homogeneity among immigrant youth as their ethnic orientations became more heterogeneous over time. Within an acculturation framework, this phenomenon asks for further investigation.

The presented study has limitations. Although the design allowed for the first time a longitudinal analysis of ethnic retention with adequate panel data in a comparative 
perspective for an important transition in the lives, the observed time span was short, which limited the empirical test of the downward assimilation hypothesis. Moreover, important variables, which may have an effect on the dynamics between educational career and ethnic retention, may have been missing, such as amplifying effects of parents' and teachers' reactions to negative developments in the academic career, or the selfselection of the adolescents into less supportive peer-environments. The level of ethnic retention is closely associated with opportunity structures not varying in the observed period, such as the proportion of co-ethnic individuals in the receiving society, the size of the local ethnic community, and the ethnic composition of the neighborhood and of schools. However, it is an open research question, whether the likelihood of change in ethnic retention is also determined by such differences in opportunity structures.

Thus, it might be too short for an assessment of the consequences of deprived educational aspirations for ethnic retention or reactive ethnicity. For example, such reactions may be related much more to structural placement in the occupational system and possible discrepancies between educational credentials and labor market options. Following such considerations in future research may or may not lead to dismissal of the downward assimilation hypothesis. At present, the statement of Richard Alba (1990: 337) still stands that empirical evidence has been lacking and the present study is therefore a small step on a much longer research journey.

Acknowledgements Open Access funding provided by Projekt DEAL.

\section{Appendix}

Table 7 Descriptive statistics of the model-variables for England (EN), Germany (GE), the Netherlands (NL), and Sweden (SW)

\begin{tabular}{lllll}
\hline & EN & GE & NL & SW \\
\hline Cultural difference & -.204 & -.346 & .128 & .455 \\
Parents' educational level & 3.157 & 2.698 & 2.973 & 3.324 \\
Migrant (1st generation youth) & $26.3 \%$ & $18.1 \%$ & $15.8 \%$ & $22.5 \%$ \\
Social retention & -.007 & .129 & -.186 & -.020 \\
Cultural retention & -.377 & .081 & .017 & .196 \\
Religious retention & .118 & .077 & .070 & -.219 \\
Emotional retention & .106 & .148 & .043 & -.269 \\
Academic track & $48.2 \%$ & $32.3 \%$ & $38.2 \%$ & $41.8 \%$ \\
Upward track mobility & $8.5 \%$ & $11.3 \%$ & $2.8 \%$ & $20.7 \%$ \\
Downward track mobility & $17.3 \%$ & $3.6 \%$ & $2.4 \%$ & $10.5 \%$ \\
Educational aspirations & .238 & -.716 & .162 & .490 \\
\hline
\end{tabular}


Open Access This article is licensed under a Creative Commons Attribution 4.0 International License, which permits use, sharing, adaptation, distribution and reproduction in any medium or format, as long as you give appropriate credit to the original author(s) and the source, provide a link to the Creative Commons licence, and indicate if changes were made. The images or other third party material in this article are included in the article's Creative Commons licence, unless indicated otherwise in a credit line to the material. If material is not included in the article's Creative Commons licence and your intended use is not permitted by statutory regulation or exceeds the permitted use, you will need to obtain permission directly from the copyright holder. To view a copy of this licence, visit http://creativecommons.org/licenses/by/4.0/.

\section{References}

Alba, R. D. (1990). Ethnic identity: the transformation of White America. New Haven: Yale University Press.

Alba, R. D., \& Nee, V. (1997). Rethinking assimilation theory for a new era of immigration. International Migration Review, 31, 826-874.

Alba, R. D., \& Nee, V. (2003). Remaking the American mainstream: assimilation and contemporary immigration. Cambridge: Harvard University Press.

Allmendinger, J., \& Leibfried, S. (2003). Education and the welfare state: the four worlds of competence production. Journal of European Social Policy, 13(1), 63-81.

Allmendinger, J., \& Nikolai, R. (2010). Bildungs- und Sozialpolitik: Die zwei Seiten des Sozialstaats im internationalen Vergleich. Soziale Welt, 61(2), 105-119.

Bankston III, C. L., \& Zhou, M. (1995). Religious participation, ethnic identification, and adaptation of Vietnamese adolescents in an immigrant community. Sociological Quarterly, 36(3), 523-534.

Becker, R., \& Beck, M. (2012). Herkunftseffekte oder statistische Diskriminierung von Migrantenkindern in der Primarstufe? In R. Becker \& H. Solga (Eds.), Soziologische Bildungsforschung. Sonderheft 52 der Kölner Zeitschrift für Soziologie und Sozialpsychologie (pp. 137-163). Wiesbaden: Springer.

Becker, B., \& Gresch, C. (2016). Bildungsaspirationen in Familien mit Migrationshintergrund. In C. Diehl, C. Hunkler, \& C. Kristen (Eds.), Ethnische Ungleichheiten im Bildungsverlauf: Mechanismen, Befunde, Debatten (pp. 73-116). Wiesbaden: Springer.

Berry, J. W. (1980). Acculturation as varieties of adaptation. In A. M. Padilla (Ed.), Acculturation: Theory, models, and some new findings (pp. 9-25). Boulder: Westview.

Berry, J. W. (1997). Immigration, acculturation, and adaptation. Applied Psychology. An International Review, $46,5-34$

Berry, J. W., Phinney, J. S., Sam, D. L., \& Vedder, P. (Eds.). (2006). Immigrant youth in cultural transition. Acculturation, identity, and adaptation across national contexts. Mahwah: Erlbaum.

Cheung, S. Y. (2014). Ethno-religious minorities and labor market integration: generational advancement or decline? Ethnic and Racial Studies, 37(1), 140-160.

CIDOB (Barcelona Centre for International Affairs) and MPG (Migration Policy Group). (2015). Migration Integration Policy Index 2014 (MIPEX). www.mipex.eu. Accessed 24 Jun 2020.

Connor, P., \& Koenig, M. (2013). Bridge and barrier. Religion and immigrant occupational attainment across integration contexts. International Migration Review, 47(1), 3-38.

Crul, M. (2016). Super-diversity vs. assimilation: how complex diversity in majority-minority cities challenges the assumptions of assimilation. Journal of Ethnic and Migration Studies, 42(1), 54-68.

Crul, M. (2018). How key transitions influence school and labour market careers of descendents of Moroccan and Turkish migrants in the Netherlands. European Journal of Education, 53(4), 481-494.

Crul, M., \& Schneider, J. (2010). Comparative integration context theory: participation and belonging in new diverse European cities. Ethnic and Racial Studies, 33(7), 1249-1268.

Crul, M., \& Vermeulen, H. (2003). The second generation in Europe. International Migration Review, 37(4), 965-986.

Diehl, C., \& Schnell, R. (2006). "Reactive ethnicity" or "assimilation"? Statements, arguments, and first empirical evidence for labor migrants in Germany. International Migration Review, 40, 786-816.

Diehl, C., Fischer-Neumann, M., \& Mühlau, P. (2016). Between ethnic options and ethnic boundaries - recent Polish and Turkish migrants' identification with Germany. Ethnicities, 16(2), 236-260.

Dollmann, J. (2010). Türkischstämmige Kinder am ersten Bildungsübergang. Primäre und sekundäre Herkunftseffekte. Wiesbaden: Verlag für Sozialwissenschaften.

Dronkers, J., \& Korthals, R. (2017). Tracking in the Netherlands - ability selection or social reproduction? In H. P. Blossfeld, S. Buchholz, J. Skopek, \& M. Triventi (Eds.), Models of secondary education and social inequality. An international comparison (pp. 149-162). Elgar: Cheltham.

Esping-Andersen, G. (1990). The three worlds of welfare capitalism. Cambridge: Polity Press. 
Gans, H. J. (1979). Symbolic ethnicity: the future of ethnic groups and cultures. Racial and Ethnic Studies, 2(1), 1-20.

Glick, J. E., \& White, M. J. (2004). Post-secondary school participation of immigrant and native youth: the role of familial resources and educational expectations. Social Science Research, 33(2), 272-299.

Hadjar, A., \& Scharf, J. (2019). The value of education among immigrants and non-migrants and how this translates into educational aspirations: a comparison of four European countries. Journal of Ethnic and Migration Studies, 45(5), 711-734.

Hansen, M. L. (1938). The problem of the third generation immigrant. Rock Island: Augustana Historical Society Publications.

Heath, A., Jacob, K., \& Richards, L. (2018). Young people in transition: the national identity of minority youth. In F. Kalter, J. O. Jonsson, F. van Tubergen, \& A. Heath (Eds.), Growing up in diverse societies. The integration of children of immigrants in England, Germany, the Netherlands and Sweden (pp. 274 302). Oxford: Oxford University Press.

Hensen-Reifgens, K. A., \& Hippach-Schneider, U. (2014). Germany. In VET in Europe - country report 2014. Bonn: Federal Institute for Vocational Education and Training.

Hofstede, G. (2001). Culture's consequences: comparing values, behaviors, institutions, and organizations across nations (2nd ed.). Thousand Oaks: Sage.

Hofstede, G., Hofstede, G. J., \& Minkov, M. (2010). Cultures and organizations: software of the mind (3rd ed.). New York: McGraw-Hill.

Jacob, K., \& Kalter, F. (2013). Intergenerational change in religious salience among immigrant families in four European countries. International Migration, 51(3), 38-56.

Jonsson, J. O. (2018). Immigration and integration: key characteristics of host countries and their immigrants. In F. Kalter, J. O. Jonsson, F. van Tubergen, \& A. Heath (Eds.), Growing up in diverse societies. The integration of children of immigrants in England, Germany, the Netherlands and Sweden (pp. 40-61). Oxford: Oxford University Press.

Kalter, F., \& Heath, A. (2018). Dealing with diverse diversities: defining and comparing minority groups. In F. Kalter, J. O. Jonsson, F. van Tubergen, \& A. Heath (Eds.), Growing up in diverse societies. The integration of children of immigrants in England, Germany, the Netherlands and Sweden (pp. 62-82). Oxford, UK: Oxford University Press.

Kalter, F., Heath, A. F., Hewstone, M., Jonsson, J. O., Kalmijn, M., Kogan, I., et al. (2016). Children of immigrants longitudinal survey in four European countries (CILS4EU) - reduced version (1.2.0 ed.). Cologne: GESIS data archive.

Kalter, F., Kogan, I., \& Dollmann, J. (2019). Studying integration from adolescence to early adulthood: design, content, and research potential of the CILS4EU-DE data. European Sociological Review, 35(2), 280-297.

Kao, G., \& Tienda, M. (1995). Optimism and achievement: the educational performance of immigrant youth. Social Science Quarterly, 76(1), 1-19.

Kao, G., \& Tienda, M. (1998). Educational aspirations of minority youth. American Journal of Education, 106(3), 349-384.

Kaufmann, F. X. (2013). Variations of the welfare state. Berlin: Springer.

Kittel, B. (2006). A crazy methodology?: on the limits of macro-quantitative social science research. International Sociology, 21(5), 647-677.

Koenig, M., Maliepaard, M., \& Güveli, A. (2016). Religion and new immigrants' labor market entry in Western Europe. Ethnicities, 16(2), 213-235.

Kristen, C., \& Dollmann, J. (2010). Sekundäre Effekte der ethnischen Herkunft: Kinder aus türkischen Familien am ersten Bildungsübergang. In J. Baumert, K. Maaz, \& U. Trautwein (Eds.), Bildungsentscheidungen. Sonderheft 12 der Zeitschrift für Erziehungswissenschaft (pp. 205-229). Wiesbaden: Verlag für Sozialwissenschaften.

Lee, J., \& Zhou, M. (2015). The Asian American achievement paradox. New York: Russell Sage.

Leszczensky, L. (2018). (Not) A matter of religion? The development of social integration among recent Christian and Muslim immigrants. Zeitschrift für Soziologie, 47(2), 119-133. https://doi.org/10.1515 /zfsoz-2018-1008.

Liu, A., \& Xie, Y. (2016). Why do Asian Americans academically outperform Whites? The cultural explanation revisited. Social Science Research, 58, 210-226.

McMullin, P., \& Kulic, N. (2017). Onwards or upwards? - the role of subject choice and schools in the reproduction of educational inequality in England. In H. P. Blossfeld, S. Buchholz, J. Skopek, \& M. Triventi (Eds.), Models of secondary education and social inequality. An international comparison (pp. 213-231). Cheltenham: Elgar. 
Müller, W., \& Shavit, Y. (1998). The institutional embeddedness of the stratification process. In Y. Shavit \& W. Müller (Eds.), From school to work (pp. 1-48). Oxford: Oxford University Press.

Nauck, B. (2008). Acculturation. In F. J. R. van de Vijver, D. A. van Hemert, \& Y. Poortinga (Eds.), Multilevel analysis of individuals and cultures (pp. 379-409). New York: Erlbaum.

Nauck, B. (2019). Ethnic inequality in educational attainment. In R. Becker (Ed.), Research handbook on sociology of education (pp. 499-518). Cheltenham: Edward Elgar.

Nauck, B., \& Genoni, A. (2019). Status transition in the educational system and well-being of migrant adolescents in cross-national comparison. In I. Gogolin \& K. Maaz (Eds.), Migration und Bildungserfolg. Sonderheft 34 der Zeitschrift für Erziehungswissenschaft (pp. 47-69). Wiesbaden: Springer.

Nauck, B., \& Schnoor, B. (2015). Against all odds? Bildungserfolg in vietnamesischen und türkischen Familien in Deutschland. Kölner Zeitschrift für Soziologie und Sozialpsychologie, 67(4), 633-657.

Ohlendorf, D., Koenig, M., \& Diehl, C. (2017). Religion and ethnic educational inequalities - theoretical arguments, empirical findings and open questions. Kölner Zeitschrift für Soziologie und Sozialpsychologie, 69(4), 561-591.

Park, R. E. (1950). Race and culture. Glencoe: Free Press.

Platt, L. (2014). Is there assimilation in minority groups' national, ethnic and religious identity? Ethnic and Racial Studies, 37(1), 46-70.

Portes, A., \& Rumbaut, R. G. (2001). Legacies: the story of the immigrant second generation. Berkeley/New York: University of California Press \& Russell Sage.

Portes, A., \& Zhou, M. (1993). The new second generation: segmented assimilation and its variants among Post1965 immigrant youth. The Annals of the American Academy of Political and Social Science, 530, 74-98.

Portes, A., Fernández-Kelly, P., \& Haller, W. (2005). Segmented assimilation on the ground: the new second generation in early adulthood AU - Portes, Alejandro. Ethnic and Racial Studies, 28(6), 1000-1040.

Relikowski, I. (2012). Primäre und sekundäre Effekte am Übertritt in die Sekundarstufe I. Zur Rolle von sozialer Herkunft und Migrationshintergrund. Wiesbaden: Springer.

Relikowski, I., Schneider, T., \& Blossfeld, H. P. (2010). Primäre und sekundäre Herkunftseffekte beim Übergang in das gegliederte Schulsystem: Welche Rolle spielen soziale Klasse und Bildungsstatus in Familien mit Migrationshintergrund? In T. Beckers, K. W. Birkelbach, J. Hagenah, \& U. Rosar (Eds.), Komparative empirische Sozialforschung. Anwendungsfelder und aktuelle Methoden in Best PracticeStudien (pp. 143-167). Wiesbaden: Verlag für Sozialwissenschaften.

Relikowski, I., Yilmaz, E., \& Blossfeld, H. P. (2012). Wie lassen sich die hohen Bildungsaspirationen von Migranten erklären? Eine Mixed-Methods-Studie zur Rolle von strukturellen Aufstiegschancen und individueller Bildungserfahrung. In R. Becker \& H. Solga (Eds.), Soziologische Bildungsforschung. Sonderheft 52 der Kölner Zeitschrift für Soziologie und Sozialpsychologie (pp. 111-136). Wiesbaden: Springer.

Rudolphi, F., \& Erikson, R. (2017). Social selection in formal and informal tracking in Sweden. In H. P. Blossfeld, S. Buchholz, J. Skopek, \& M. Triventi (Eds.), Models of secondary education and social inequality. An international comparison (pp. 165-180). Cheltenham: Elgar.

Rumbaut, R. G. (1994). The crucible within: ethnic identity, self-esteem, and segmented assimilation among children of immigrants. International Migration Review, 28(4), 748-794.

Salikutluk, Z. (2016). Why do immigrant students aim high? Explaining the aspiration-achievement paradox of immigrants in Germany. European Sociological Review, 32(5), 581-592.

Salö, L., Ganuza, N., Hedman, C., \& Karrebaek, M. S. (2018). Mother tongue instruction in Sweden and Denmark. Language policy, cross-field effects, and linguistic exchange rates. Language Policy, 17(4), 591-610.

Thomson, M., \& Crul, M. (2007). The second generation in Europe and the United States: how is the transatlantic debate relevant for further research on the European second generation? Journal of Ethnic and Migration Studies, 33(7), 1025-1041.

van de Werfhorst, H. G. \& Tubergen, F. (2007). Ethnicity, schooling, and merit in the Netherlands. Ethnicities, 7(3), 416-444.

Van de Werfhorst, H. G., \& Mijs, J. J. (2010). Achievement inequality and the institutional structure of educational systems: a comparative perspective. Annual Review of Sociology, 36, 407-428.

West, A., \& Nikolai, R. (2013). Welfare regimes and education regimes: equality of opportunity and expenditure in the EU (and US). Journal of Social Policy, 42(3), 469-493.

Zhou, M. (1997). Segmented assimilation: issues, controversies, and recent research on the new second generation. International Migration Review, 31(4), 975-1008.

Publisher's Note Springer Nature remains neutral with regard to jurisdictional claims in published maps and institutional affiliations. 